\title{
Differential Regulation of Drought Responses in Two Phaseolus vulgaris Genotypes
}

\author{
Cristina María López (1), Manuel Pineda (1) and Josefa M. Alamillo* \\ Departamento de Botánica, Ecología y Fisiología Vegetal, Grupo de Fisiología Molecular y Biotecnología de \\ Plantas, Campus de Excelencia Internacional Agroalimentario, CEIA3, Campus de Rabanales, Edif. Severo \\ Ochoa, Universidad de Córdoba, 14071 Córdoba, Spain; b22lovac@uco.es (C.M.L.); bb1piprm@uco.es (M.P.) \\ * Correspondence: bv1munaj@uco.es
}

Received: 25 November 2020; Accepted: 20 December 2020; Published: 21 December 2020

\begin{abstract}
Drought is probably the most harmful stress affecting common bean crops. Domestication, worldwide spread and local farming practices has entailed the development of a wide variety of common bean genotypes with different degrees of resistance to water stress. In this work, physiological and molecular responses to water stress have been compared in two common bean accessions, PHA-0683 and PMB-0220, previously identified as highly and moderately resistant to water stress, respectively. Our hypothesis was that only quantitative differences in the expression patterns of key genes should be found if molecular mechanisms regulating drought resistance are similar in the two accessions. However, results presented here indicate that the resistance to drought in PMB-0220 and PHA-0683 common bean accessions is regulated by different molecular mechanisms. Differential regulation of $\mathrm{ABA}$ synthesis and ABA signaling related genes among the two genotypes, and the control of the drought-induced senescence have a relevant contribution to the higher resistance level of PHA-0683 accession. Our results also suggest that expression patterns of key senescence-related transcription factors could be considered in the screening for drought resistance in common bean germplasm collections.
\end{abstract}

Keywords: ABA-responses; landraces; common bean; resistance; senescence; WRKY transcription factors

\section{Introduction}

Drought is one of the most harmful abiotic stresses affecting yield of common bean (Phaseolus vulgaris) crops, with a great economic and dietary importance, especially in developing countries. Moreover, current climate change and its associated increase of drought episodes are expected to worsen the negative effect of water stress in crops productivity worldwide [1-4]. Like other legumes, common bean can use atmospheric nitrogen $\left(\mathrm{N}_{2}\right)$ through the symbiotic fixation process [5], thus allowing a reduced use of fertilizers, promoting a more sustainable agriculture. Typically, the uredic legumes such as common bean (P. vulgaris) and soybean (Glycine max) transport the symbiotically fixed nitrogen in the form of the ureides, allantoin and allantoate, whereas most temperate legumes transport their $\mathrm{N}$ in the form of amides [6,7]. Symbiotic nitrogen fixation is rapidly inhibited under conditions of water stress [8], and the ureidic legumes are in general more susceptible than the amidic ones. Several studies suggested that accumulation of ureides during water stress could be related with the inhibition of symbiotic fixation in ureidic legumes [9]. In contrast, subsequent studies have shown that nodule activity in plants subjected to drought is inhibited earlier than the accumulation of ureides in these plants [10-12]. Up to now, there is no a clear relationship between ureides concentration and inhibition of symbiotic fixation during drought, but, on the contrary, also a possible protective role of ureides has been suggested in several plants, probably through their effects regulating abscisic acid (ABA) and jasmonate (JA) levels [11-14]. 
The phytohormone abscisic acid (ABA) is a key regulator of the plant response to abiotic stressors, but especially to osmotic and water deficit stress. The biosynthesis of this hormone is activated in response to dehydration, through the oxidative cleavage of carotenoids. In contrast, its degradation is induced by rehydration [15], modulating the ABA content according to the environmental conditions. The first steps of its synthesis, from $\beta$-carotene to xanthoxin, occur in the plastids, while the final steps take place in the cytosol $[16,17]$. ABA regulates a plethora of physiological processes, as stomatal closure, growth, as well as dormancy and germination of seeds [18-20]. ABA-mediated responses are also involved in the regulation of other plant developmental processes such as leaf senescence and abscission [21]. In response to water deficit, ABA levels rise and initiates the ABA-signaling of these stress responses [22]. ABA is recognized inside the cells mainly by a family of ABA receptors named Pyrabactin Resistance (PYR)/ PYL(PYR-Like), or Regulatory Component of ABA Receptor (RCAR) $[23,24]$. In the presence of ABA, the ABA receptors PYR/PYL/RCAR bind to, and inactivate type 2C (PP2Cs) Ser/Thr protein phosphatases [23-25]. Inactivation of PP2Cs allows the activation of SnRK2 kinases (Snf1-related protein kinase class 2), which subsequently phosphorylate ABI5/ABFs transcription factors (ABA-Insensitive5/ABA-responsive element binding factors) which in turn activate the downstream effectors of the stress response [26,27].

Increases in plant resistance to water deficit have been associated to promotion of leaf senescence, in part induced by changes in ABA levels under stress conditions [21]. The outcome of leaf senescence is the mobilization of nutrients from senescent to younger tissues, as well as the death of cells with the consequent foliar abscission [28], which, in turn, reduces leaf surface and transpiration rates. It has been suggested that ABA-induced senescence was promoted by the biosynthesis of ethylene [29]. However, more recent studies showed that, in Arabidopsis thaliana, ABA-induced foliar senescence is mediated by an ethylene independent pathway, through direct inhibition of PP2Cs, activation of SnRK2s and activation of the downstream signaling pathway [30]. Among the downstream genes involved in activation of senescence and ABA-mediated responses to drought are some of the WRKY transcription factors (TF) [31,32]. WRKY proteins constitute large families that have been classified into three groups depending on its characteristic WRKY domains and zinc finger motifs [33]. The number of WRKY proteins varies in each species, with 74 and 88 WRKY genes identified in Arabidopsis and P. vulgaris, respectively [34,35], while up to 197 WRKY proteins have been found in G. max (soybean) [36]. Although WRKY TFs have been extensively studied in a wide variety of plants, their specific roles in the regulation of drought resistance and senescence in legumes is still largely unknown.

Although common bean is susceptible to drought conditions, finding varieties better adapted to environmental stresses will have a major impact on crop yields and human nutrition, particularly in developing countries [37]. The domestication processes and local farming practices have led to the development of a wide variety of common bean genotypes with different degrees of resistance to drought stress $[3,38]$. Characterization of a high number of accessions from the common bean Spanish collection revealed superior performance of several accessions under water scarcity conditions. From these the PHA-0683 landrace appeared as a high yield resistant genotype, whereas the commercial breeding line Great Northern PMB-0220 ranked as a slightly less drought-resistant line [39].

Although resistance to drought has been evaluated in many collections of bean germplasm, obtaining varieties resistant to water stress while keeping good productivity is a complex task, because resistance to drought is a trait largely affected by environmental interactions with additive and quantitative effects $[40,41]$. Molecular analyses, boosted by the recent release of common bean genomes, are important tools to understand how drought resistance is achieved in these crops. Genome-wide drought responsive genes have been identified by transcriptomic analysis in several legume crops [42-44], including common bean [45,46].

Previous studies from our group showed that PHA-0683 landrace, besides showing a high yield performance, was also able to maintain good rates of $\mathrm{N} 2$ fixation and did not accumulate ureides in response to the drought stress [12]. On the other hand, the PMB-0220 line showed a good level of resistance to drought, although lower than that of PHA-0683 [12,39,40]. In addition, a genome wide 
transcriptomic analysis of differentially expressed genes under drought conditions in the resistant common bean PHA-0683 landrace, identified changes in ABA signaling-related genes and several key transcription factors known to regulate stress and developmental responses [47].

The hypothesis of the actual work was that the different degree in resistance in the two genotypes studied here should be caused by differential regulation at the molecular level. Therefore, only quantitative differences will be expected, if the higher level of resistance in PHA-0683 and the lower in PMB-0220 are governed by similar regulatory mechanism. In contrast, qualitative differences in the expression patterns of key factors would reveal different mechanisms of resistance to stress in these two genotypes. Therefore, the main aim of this work was the comparison of physiological and molecular responses to drought in the common bean PHA-0683 and PMB-0220 accessions.

\section{Results}

To determine if the different degrees of resistance to water stress in two common bean genotypes are indeed mediated by differential molecular responses, the highly tolerant PHA-0683 landrace and the PMB-0220 breeding line [12,39] were subjected to 10 days of water deficit and the responses were compared to those of the well-irrigated, control plants, from each genotype.

\subsection{Physiological Effects of Drought in Two Common Bean Drought Tolerant Plants}

Drought effects on the relative water content of soil and leaves and in the plant biomass were compared between the control plants and the plants subjected to 10 days of water deficit on the PHA-0683 landrace and the PMB-0220 breeding line.

The results in Figure 1A show that the soil moisture (relative soil water content) was above $80 \%$ of soil water capacity (field capacity) in the control group of both cultivars, whereas, after 10 days of drought treatment, soil water content decreased up to $40 \%$ in the PMB-0220 line and up to 50\% SWC in the PHA-0683, thus suggesting that PHA-0683 plants used less water from soil than PMB-0220 ones. However, despite the shortage in available soil water content, there were no significant differences in the relative leaf water content (LWC) between control and drought conditions in any of the two cultivars (Figure 1B). Nevertheless, while PHA-0683 did not show any reduction in leaf water content after the water stress, a slight decrease in LWC was found in leaves of PMB-0220, agreeing with the degree of drought resistance in these plants.

Determination of the effect of water deprivation in the biomass of roots and shoots showed that, although there were no significant differences in the total roots biomass between control and drought conditions in any accession, a slight increase in the biomass of roots, with respect to the control conditions, was observed in PMB-0220 plants (Figure 1C). In contrast, a significant reduction in shoot biomass was found in the water-stressed PMB-220 plants, compared to their control condition (Figure 1D). On the contrary, there were no significant differences between control and drought conditions in the aboveground biomass in PHA-0683 plants (Figure 1D). Moreover, under control conditions, similar biomass was found in the roots and shoots of the two genotypes, indicating that the moderate differences in water use and in shoot biomass were not caused by phenological or developmental differences of the plants.

\subsection{Changes in Total Chlorophyll Contents in Response to Drought}

Drought stress is known to trigger senescence symptoms leading to a reduction of chlorophyll contents in the leaves of stressed plants. To determine whether there where changes in the chlorophylls levels in response to the stress in the PMB-0220 and PMB-0683 genotypes, contents of both, chlorophylls $a$ and $b$, were measured in all the developed leaves present in plants submitted to 10 days of drought treatment and in control, well-irrigated plants (Table 1). The results, summarized in the Figure 2A, showed that the oldest leaves in the drought stressed PMB-0220 plants had lower chlorophyll content than control ones. Moreover, although chlorophylls a and $b$ were reduced in the second trifoliate leaves of PMB-0220 after 10 days of water stress, the reduction was higher in chlorophyll a than chlorophyll 
b (Table 1). Instead, the leaves of PHA-0683 drought stressed plants did not show any significant reduction in chlorophylls content with respect to its control conditions (Figure 2B). On the contrary, chlorophyll levels appeared to be slightly higher in the youngest leaves of the water-stressed PHA-0683 plants, probably reflecting the slight reduction of the area of the youngest leaves, that accounts also for the moderate decrease in shoot biomass in these plants.

A

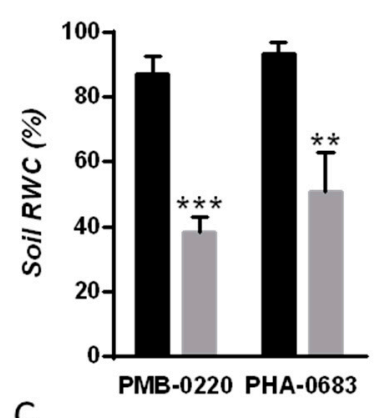

C

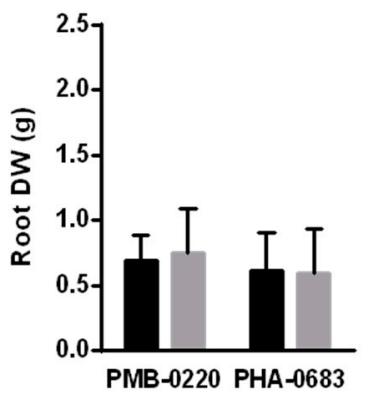

\section{B}
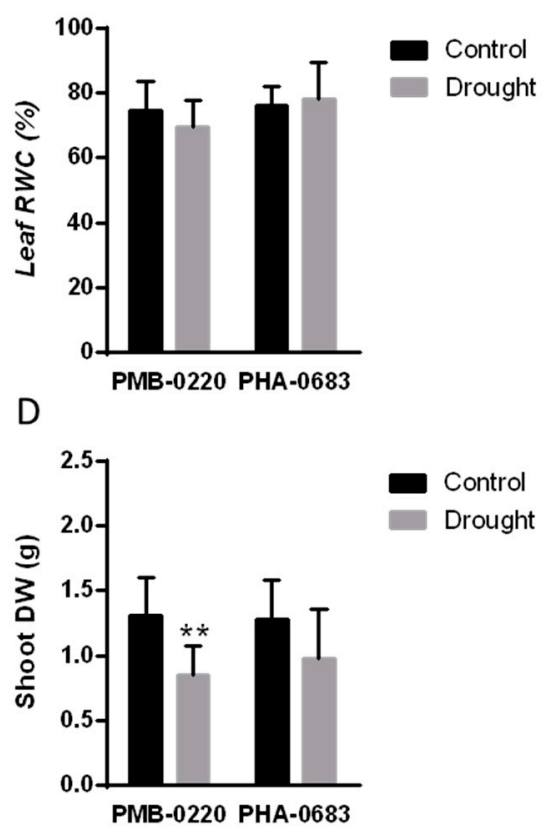

Figure 1. Physiological parameters of control and 10 days water deficit stressed plants of common bean PMB-0220 breeding line and PHA-0683 landrace, grown under symbiotic nitrogen fixation conditions for 28 days before the stress treatment. Relative water content of (A) soil and (B) leaf, and biomass of $(\mathbf{C})$ roots and (D) shoots. Data are means of three independent experiments and asterisks indicate statistically significant differences $(* * p<0.005)$ and $(* * *<0.0005)$.

Table 1. Concentration of chlorophyll a, b and total chlorophyll in the 2nd, 3rd, 4th and 5th trifoliate leaves of $P$. vulgaris PMB-0220 and PHA-0683 subjected to well-watered and water deficit conditions for 10 days.

\begin{tabular}{cllccccc}
\hline & \multicolumn{2}{c}{ [Chlorophyll a] } & \multicolumn{2}{c}{ [Chlorophyll b] } & \multicolumn{2}{c}{ [Chlorophyll a + b] } \\
\cline { 2 - 8 } & & PMB-0220 & PHA-0683 & PMB-0220 & PMB-0683 & PMB-0220 & PHA-0683 \\
\hline \multirow{2}{*}{ 2nd TFL } & Control & $1.270 \pm 0.209$ & $1.475 \pm 0.279$ & $0.634 \pm 0.115$ & $0.732 \pm 0.151$ & $2.013 \pm 0.336$ & $2.362 \pm 0.417$ \\
\cline { 2 - 8 } & Drought & $0.501 \pm 0.144$ & $1.485 \pm 0.201$ & $0.429 \pm 0.207$ & $0.634 \pm 0.070$ & $1.078 \pm 0.451$ & $2.329 \pm 0.294$ \\
\hline \multirow{2}{*}{ 3rd TFL } & Control & $1.664 \pm 0.225$ & $1.673 \pm 0.160$ & $0.789 \pm 0.146$ & $0.873 \pm 0.148$ & $2.880 \pm 0.085$ & $2.795 \pm 0.317$ \\
\cline { 2 - 8 } & Drought & $1.452 \pm 0.195$ & $1.589 \pm 0.186$ & $0.704 \pm 0.071$ & $0.729 \pm 0.044$ & $2.246 \pm 0.140$ & $2.546 \pm 0.230$ \\
\hline \multirow{2}{*}{ 4rd TFL } & Control & $1.599 \pm 0.215$ & $1.669 \pm 0.172$ & $0.891 \pm 0.082$ & $0.877 \pm 0.125$ & $2.867 \pm 0.142$ & $2.798 \pm 0.267$ \\
\cline { 2 - 8 } & Drought & $1.546 \pm 0.251$ & $1.657 \pm 0.148$ & $0.778 \pm 0.118$ & $0.906 \pm 0.148$ & $2.551 \pm 0.294$ & $2.813 \pm 0.267$ \\
\hline \multirow{2}{*}{ 5th TFL } & Control & $1.587 \pm 0.178$ & $1.797 \pm 0.174$ & $0.687 \pm 0.156$ & $0.886 \pm 0.125$ & $2.685 \pm 0.166$ & $2.950 \pm 0.251$ \\
\cline { 2 - 8 } & Drought & $1.628 \pm 0.134$ & $1.776 \pm 0.160$ & $0.779 \pm 0.191$ & $0.889 \pm 0.297$ & $2.644 \pm 0.206$ & $2.926 \pm 0.487$ \\
\hline
\end{tabular}

\subsection{Analysis of Genes Expression Related to ABA-Mediated Response}

In a previous study, several genes of the core ABA signaling were found to change in response to drought in the highly resistant PHA-0683 landrace [47]. To elucidate whether similar ABA-mediated responses take place in the PMB-0220 line, levels of relative expression of key genes for ABA synthesis 
(9-Cisepoxycarotenoid Dioxygenase, NCED), degradation ((+)-Abscisic acid 8'-Hydroxylase, ABA 8'H), ABA signaling (type $2 \mathrm{C}$ protein phosphatases, $\mathrm{PP} 2 \mathrm{Cs}$ ) and downstream responsive genes, as the proline synthesis ( $\triangle 1$-Pyrroline-5-Carboxylate Synthase, P5CS), were measured in samples of the two genotypes. Expression patterns of these ABA-related genes were compared in leaf tissues from control and from plants subjected to 10 days of drought from each genotype (Figure 3A-D). As shown in Figure 3A-D, the relative expression of PvNCED3, PvABA8'H and PvP5CS10, coding for ABA synthesis, ABA degradation and ABA-responsive genes, respectively, was significantly induced by drought in the PMB-0220 line. In contrast, the expression of these genes was repressed by water deprivation in PHA-0683. On the other hand, PvPP2C.12, coding for a phosphatase $2 \mathrm{C}$ involved in repression of ABA-responses [48], showed a reduction in its levels under drought conditions in both cultivars (Figure 3C), although PvPP2C.12 gene expression was only highly repressed under drought conditions in PHA-0683, with only a slight, no significant decrease of expression levels in PMB-0220 samples (Figure 3C).
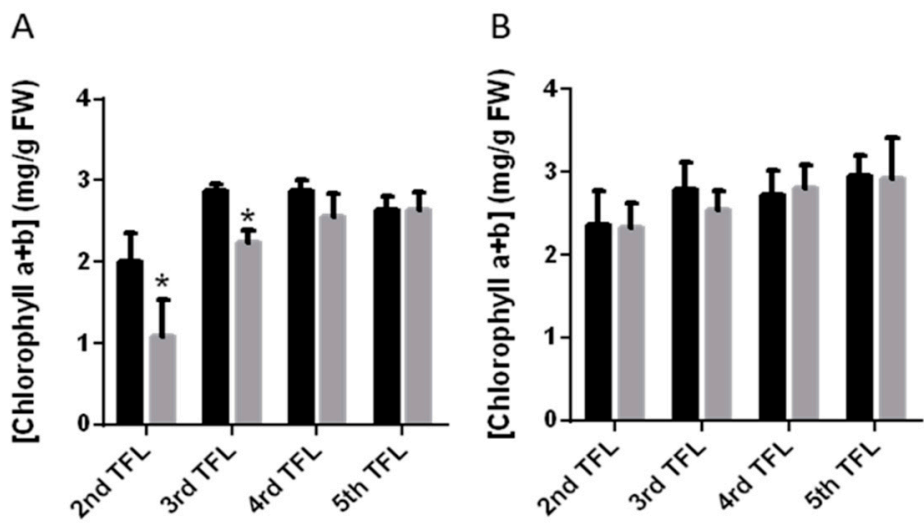

Figure 2. Concentration of chlorophylls in the 2nd, 3rd, 4th and 5th trifoliate leaves of P. vulgaris PMB-0220 (A) and PHA-0683 (B) plants under control conditions and after 10 days of drought. Data were means of three independent repetitions, and 3 plants were used per sample in each replicate. Asterisks indicate statistically significant differences $\left({ }^{*} p<0.05\right)$.

A

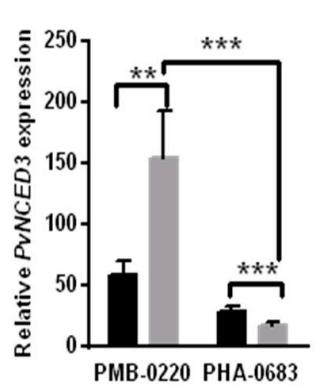

B

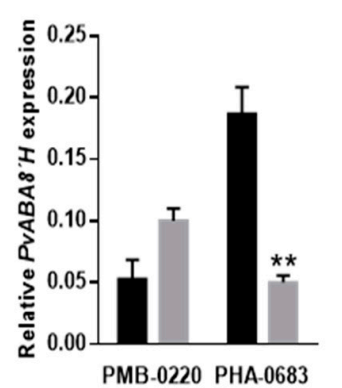

$\mathrm{C}$

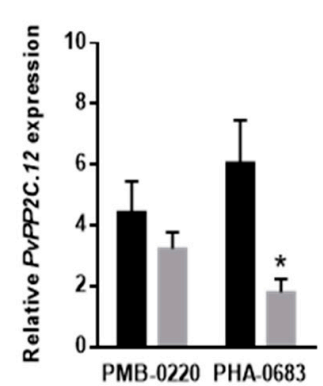

D

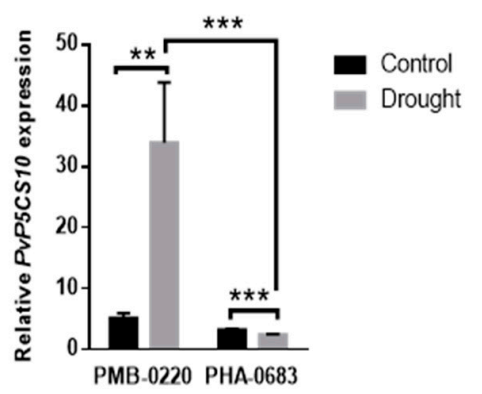

Figure 3. Relative expression of abscisic acid (ABA)-related genes in leaves from control and 10 days-drought-stressed plants of PMB-0220 and PHA-0683 lines, grown under symbiotic nitrogen fixation conditions. Relative expression of (A) PvNCED3; (B) PvABA8'H; (C) PvPP2C.12 and (D) PvP5CS10 in response to drought. Data were means of three independent samples and asterisks indicate statistically significant differences $(* p<0.05)\left({ }^{* *} p<0.005\right)$ and $(* * p<0.0005)$.

\subsection{Analysis of Genes Expression Related to Senescence in Response to Drought}

To investigate if the differences in the ABA-related genes among the two genotypes could also be observed in transcription factors involved in key processes affecting drought resistance in the PMB -0220 and PHA-0683 lines, the expression of several genes related to the activation or inhibition of senescence, and whose expression could be mediated by ABA levels, was measured in leaf samples from control 
and drought stressed plants from the two genotypes. The results in the Figure $4 \mathrm{~A}-\mathrm{C}$ show that the drought-mediated changes in the expression of three genes encoding WRKY TF exhibited significant differences between the PMB-0220 and PHA-0683 plants in response to the stress. Expression of PvWRKY53 gene, directly related with induction of senescence $[49,50]$, showed a significant induction after 10 days of drought with respect to its well-irrigated control in the PMB-0220 line (Figure 4A). On the contrary, there were no significant differences in expression of PvWRKY53 between the control and stressed leaf tissues in the PHA-0683 plants (Figure 4A). However, PvWRKY53 showed a higher expression level under control conditions in PHA-0683 than in PMB-0220. Moreover, the expression patterns of $P v W R K Y 57$, also related to induction of senescence and drought resistance [51], were similar to these of PvWRKY53 in response to drought. PvWRKY57 was significantly overexpressed at 10 days of water stress compared to the control conditions in the PMB-0220 cultivar, while in PHA-0683 there were no significant differences between control and water stressed samples, although, in this landrace, PvWRKY57 was overexpressed with respect PMB-0220 (Figure 4B). In addition, the PvWRKY70 gene, which has been related with inhibition of senescence [52], showed an opposite expression pattern in one cultivar or the other during drought conditions. PvWRKY70 was significantly downregulated under drought conditions in PMB-0220, whereas it showed an induction of its expression at 10 days of water stress in leaves from PHA-0683 plants. Finally, the results presented in Figure 4D-F show that the expression of genes coding for MYC and MYB transcription factors involved in the responses to abiotic stress was also different among the two common bean genotypes. PvMYC was slightly downregulated under drought conditions in both cultivars, but its expression was significantly higher in the control and drought conditions in PMB-0220 than in PHA-0683. In contrast, two MYB genes, PvMYB03 and PvMYB07, showed a significant induction of their expression after 10 days of drought in each genotype, although the level of induction was also higher in the common bean PMB-0220 than in the PHA-0683.

A

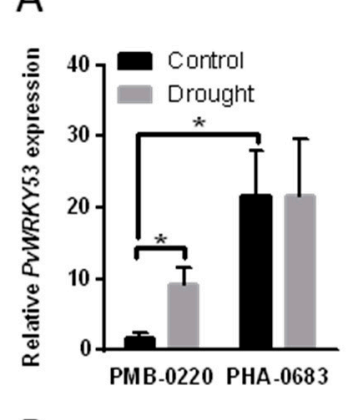

$\mathrm{D}$

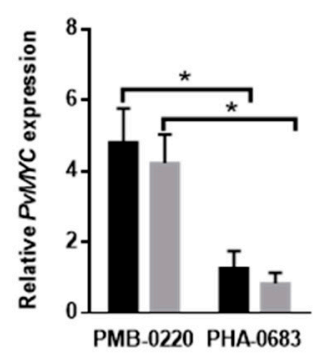

B

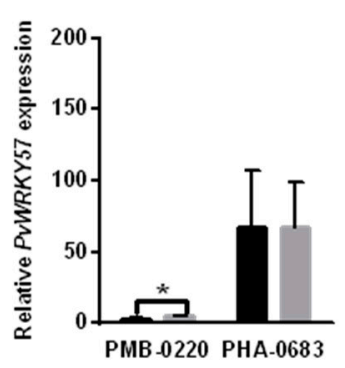

$\mathrm{E}$

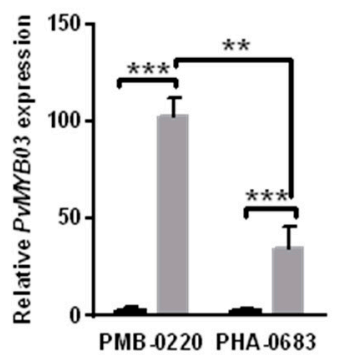

$\mathrm{C}$

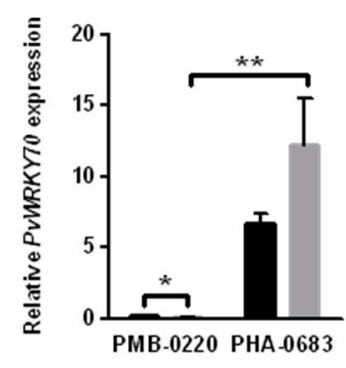

$\mathrm{F}$

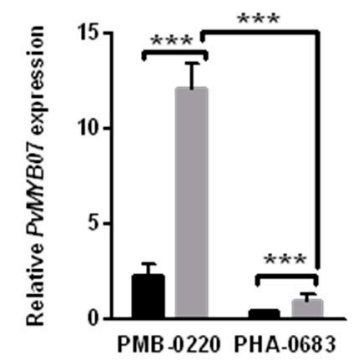

Figure 4. Relative expression of key transcription factors related with senescence and drought responses in leaves from control and 10 days-drought-stressed PMB-0220 and PHA-0683 plants, grown under symbiotic nitrogen fixation conditions. Relative expression of (A) PvWRKY53; (B) PvWRKY57; (C) PvWRKY70; (D) PvMYC; (E) PvMYB03; and (F) PvMYB07 in response to drought. Data are means of three independent experiments and asterisks indicate statistically significant differences $\left({ }^{*} p<0.05\right)$ $(* * p<0.005)$ and $(* * *<0.0005)$. 


\section{Discussion}

The search for drought resistant common bean varieties has increased due to the worsening of drought episodes by the current climate change conditions [37]. Most research until now has focused on the search for the most productive genotypes, based on the physiological and agronomical characterization of cultivars or landraces that evolved under such unfavorable conditions, or that have been obtained in breeding programs $[39,40]$. These studies have revealed that there are large phenotypic differences in the drought tolerance in common bean genotypes [3]. However, despite the large effort posed in the search for drought-resistant common bean lines, studies aimed to dissect the molecular mechanism that govern these phenotypic differences are scarce till now. In this work, molecular and physiological responses of two common bean genotypes have been compared. From these, landrace PHA-0683 ranked as a highly drought-resistant genotype, whereas PMB-0220 was a commercial high yielding line, that ranked as moderately resistant to drought conditions [39]. In a recent genome wide transcriptomic analysis in leaf tissue of PHA-0683 landrace, differential expression of key genes related with ABA-mediated responses and the regulation of senescence by drought was observed [47].

The results in physiological parameters shown in Figure 1 revealed that there were no significant differences in the leaf relative water content and biomass accumulation between the control and drought-stressed plants of PHA-0683 landrace, with only a slight reduction in the shoot biomass after 10 days of water stress (Figure 1D), which correlated to a discrete reduction in the number of pods and seeds caused by water deficit in field experiments [39]. However, common bean PMB-0220 breeding line showed a significant decrease in shoot biomass and a slight increase in root biomass under drought conditions against control conditions (Figure 1C,D). This slight root growth is a common response related to the need to reach soil layers with higher moisture levels [53]. The decrease in aerial dry matter in both cultivars also corresponded to a general slow-down of cell expansion, to reduce the gas exchange surface and the loss of water in the leaves in response to water scarcity. Moreover, the smaller effects observed in the drought-stressed PHA-683 plants agrees with the higher level of drought resistance reported for this landrace in comparison with the PMB-220 breeding line. Noteworthy, most of the physiological and phenological parameters related to growth habits, days to flowering, shoot and root biomass are similar in the two common bean genotypes [39]. Therefore, the small increase in root and decrease in shoot biomass in PMB-0220, but not in PHA-0683, should be explained as a differential response to drought, in turn, caused by metabolic and molecular changes in the two lines. Moreover, the higher relative soil water content after the water deficit treatment in the PHA-0683 landrace strongly suggests that this genotype is better adapted to restrict water loss, probably through a faster ABA-mediated stomatal closure [20,54].

In a previous study, the transcriptome changes in response to drought showed down-regulation of genes coding for proteins that are repressors of ABA signaling, as the PP2Cs, and of ABA degradation, as $\mathrm{ABA} 8^{\prime}$ hydroxylase, suggesting that ABA-mediated responses were activated in PHA-0683 landrace. [47]. In this work we have compared the expression levels of genes coding for key enzymes in ABA synthesis, as the 9-cis-epoxycarotenoid dioxygenase (NCED) [55], signaling as phosphatase PP2C, degradation as ABA 8' hydroxylase, and ABA-responsible genes, like the one coding P5CS, involved in the synthesis of proline.

Abscisic acid is synthesized de novo in response to dehydration, through transcriptional regulation of ABA biosynthetic genes [56]. Several studies have shown that NCED was the key enzyme involved in ABA biosynthesis [57,58]. Nine NCED genes have been identified in Arabidopsis thaliana, of which NCED3 (AtNCED3) controlled the level of endogenous ABA under drought stress conditions [56]. In P. vulgaris there are three NCED-related genes, from which Phvul.005G051600 showed the highest homology to NCED3 from Arabidopsis and was the one chosen in this analysis.

In PMB-0220 plants, PvNCED3 showed a significantly higher level of expression in drought-stressed than in control leaves (Figure 3A), suggesting induction of the synthesis of ABA during water deficit conditions. In contrast, the expression level of PvNCED3 was lower under drought conditions with respect to the control in PHA-0683 landrace, and it was also lower than in water-stressed samples 
from the PMB-0220 genotype (Figure 3A). In contrast, the PvABA8'H and PvPP2C.12 genes were down-regulated by water stress in PHA-0683, with respect to control conditions, while in PMB-0220, these genes were either up-regulated, or remained unchanged in response to stress (Figure 3B,C). PvPP2C.12 gene encodes a PP2C phosphatase recognized as a negative regulator of ABA-mediated response [59], and $P v A B A 8^{\prime} H$ encodes the ABA-8'-hydroxylase protein that catalyzes the key oxidation step in the ABA catabolism pathway $[60,61]$. Therefore, expression patterns of these ABA-related genes strongly suggest different regulatory mechanism in the two cultivars. Thus, while water stress seems to promote the ABA biosynthesis in PMB-0220 cultivar, it reinforces the ABA-mediated responses in the PHA-0683 landrace by repressing negative regulators and inhibiting its degradation. Nevertheless, although 10 days of treatment were chosen because PHA-0683 did not show any appreciable symptoms of stress at earlier times [12], we cannot exclude that different kinetics could be responsible for these results; thus, further analysis should be done to determine whether ABA synthesis could be induced earlier in these plants.

Apart from the ABA-mediated regulation of stomatal conductance, triggering stomatal closure, ABA also promotes the synthesis of compatible metabolites such as proline, which acts as active compounds to allow osmotic adjustment during water stress [62]. Increases in proline concentration is a widespread response to drought, cold, and salt stress, often regarded as a basic strategy for the protection and survival of plants under abiotic stress. Proline accumulation is mediated by the induction of the P5CS gene, encoding a $\triangle 1$-pyrroline-5-carboxylate synthase, which catalyzes the first and rate-limiting step in the synthesis of this amino acid.

In most plants, there are two isoforms of P5CS that differ in their temporal and spatial expression patterns [63-65]. In common bean, there are four genes coding P5CS proteins, from which PvP5CS10 (Phoul.010G015400) showed the highest homology to P5CS1, responsible for the accumulation of proline under drought stress in Arabidopsis. The relative expression of PvP5CS10 increased significantly after 10 days of drought in PMB-0220 (Figure 3D), suggesting that synthesis of proline might contribute to the osmotic adjustment in these plants that showed no significant differences in the leaf RWC under water stress with respect to the control (Figure 1B). In contrast, the proline synthesis gene, PvP5CS10, was repressed compared to control conditions in the PHA-0683 plants, despite that RWC was also maintained in leaves subjected to 10 days of drought in these plants. Interestingly, genes coding for glycine-betaine were found as induced by water stress in the transcriptome analysis of this landrace [47], suggesting different osmotic adjustment mechanisms in the two genotypes. Moreover, a recent study demonstrated that concentration of proline does strongly correlate with the susceptibility to drought in common bean landraces and accessions [66], thus also agreeing with the lower resistance of the commercial cultivar PMB-0220 compared to the PHA-0683 landrace.

Besides acting as a compatible osmolyte, proline produced under stressful conditions also acts as a free radical scavenger and an activator of ROS detoxification pathways. Moreover, the accumulation of proline can function as a signaling molecule, inducing the expression of stress-responsive genes, including those encoding enzymes that scavenge ROS [67]. Accordingly, preliminary results from our group indicate that induction of some antioxidant activities, like superoxide dismutase (SOD) and catalase, were higher in PMB-0220 plants than in the PHA-0683 ones (Supplementary Figure S1)

In addition to osmotic regulation, acceleration of leaf senescence is a common response of many plants to adapt to adverse conditions [30]. Leaf senescence is a developmental process regulated via changes in hormonal balance, especially associated with the decrease in cytokinin (CKs) and increase in ABA contents, although levels of jasmonic acid (JA), ethylene, and salicylic acid are also important [68,69]. These changes in hormonal balance are transduced by transcription factors including several members of the WRKY, NAC, MYC, and MYB TF families. We found that the expression of PvWRKY53, a key gene related to the induction of senescence in Arabidopsis [49], had a significant induction in leaves of PMB-0220 plants subjected to 10 days of water stress, while there were no significant differences among drought and control samples from PHA-0683 plants (Figure 4A). On the contrary, PvWRKY70, which is considered as a senescence repressor gene in Arabidopsis [50], was significantly upregulated 
in the foliar tissue of plants subjected to drought in PHA-0683 landrace (Figure 4C), confirming the results from the transcriptome study of these plants [47]. Conversely, PvWRKY70 gene was downregulated in leaves from the PMB-0220 line subjected to drought. Besides being involved in senescence regulation, some genes coding for WRKY TFs are also directly related to the tolerance to water stress. PvWRKY53 and PvWRKY57 might be part of this group, as reported for their closest homologs in soybean (GmWRKY54) and Arabidopsis (AtWRKY57) [52,70]. The expression patterns of these TF, shown in Figure 4, strongly agree with the high tolerance of the common bean PHA-0683 landrace, where, in addition to the PvWRKY70 inhibition of foliar (Figure 4C), high levels of PvWRKY53 and $P v W R K Y 57$, found already under control conditions, may promote the protection against water stress. Moreover, the expression of WRKY genes was always higher in samples from PHA-0683 than in the those from the PMB-0220 cultivar (Figure 4A,B), thus confirming the differential behavior of these regulatory genes in the two genotypes.

Furthermore, MYB- and MYC-type transcription factors have been related with ABA and jasmonate -mediated responses that regulate tolerance to abiotic stresses as drought [51,71]. MYB transcription factors have also been associated with the regulation of senescence [72]. In this work, we investigated the expression of two MYB and one MYC encoding genes, whose expression was previously found to change in response to drought in PHA-0683 landrace [47]. Two genes that code for MYB TFs (PvMYB03 and PvMYB07) were overexpressed in PMB-0220 and PHA-0683 after 10 days of drought (Figure 4E,F), although the induction was higher in PMB-0220 than in the PHA-0683 genotype, agreeing with the induction of ABA synthesis genes in PMB-0220 plants. In contrast, the MYC-coding gene showed no significant expression changes in any of the two lines, but, again, its expression levels were higher in the leaves from PMB-0220 than in those from PHA-0683 plants.

Analysis of the promoter regions of PvWRKY53, PvWRKY57, and PvWRKY70 genes revealed that they contain several cis-acting elements related to the binding of MYC and MYB TF. Moreover, the promoters of these WRKY genes also contain other stress-related cis-acting elements, such as ABRE (ABA responsive element), TCA-element (salicylic acid responsive element), CGTCA/TGACG-motif (MeJa responsive element), P-box (gibberellin-responsive element), and TGA-element (auxin-responsive element) (Supplementary Table S1). The presence of several abiotic stress-related motives in the WRKY genes suggests that, indeed, they would play a prominent role in drought resistance in the two common bean cultivars. On the other hand, WRKY TFs regulate the expression of downstream genes involved in general features of senescence, as remobilization processes and induction of antioxidant enzymes. In fact, direct interaction of WRKY53 with the promoter of catalase genes has been reported [73]. Accordingly, we found induction of catalase activity only in drought-stressed leaves from PMB-0220, agreeing with the induction of PvWRKY53 expression in these plants, but not in the PHA-0683 ones.

Chlorophyll degradation is among the early symptoms of leaf senescence [74,75]. Determination of chlorophyll concentration in the two common bean genotypes revealed that chlorophyll degradation occurred earlier in the PMB-0220 than in the PHA-0683 plants submitted to water stress (Table 1; Figure 2). These results coincided with the more pronounced decrease in the aerial biomass under water stress in PMB-0220 plants and with the expression patterns of PvWRKY53 and PvWRKY70, found in these two genotypes.

Regulation of senescence under drought conditions may have both beneficial and detrimental effects and there are studies showing that the delay of foliar senescence is related to resistance to water deficit [21]. Contrary, there are many other reports highlighting that the increase in ABA levels directly promotes senescence, with the consequent remobilization of nutrients from senescing organs to the youngest tissues $[30,76,77]$. Inhibition of leaf senescence in PHA-0683 plants under drought is also consistent with a lower induction of NCED gene controlling ABA synthesis, compared to the results in PMB-0220 accession (Figure 3A). This also agrees with previously reported results showing that PHA-0683 plants are able to maintain symbiotic nitrogen fixation, reducing the need for nutrient remobilization [12]. In contrast, the promotion of senescence in the oldest leaves of PMB-0220 plants might help to acquire the required nitrogen to nourish young tissues under the water stress, thus also 
contributing to the drought resistance of these plants. Although further data are required to ascertain whether control of senescence is a unique adaptation of PHA-0683 landrace, or, instead, it could have an important role in the resistance of other common bean genotypes. Moreover, our results highlight the need to implement more broad-range molecular analysis, including whole genome sequencing and transcript abundance under environmentally stressful conditions in different bean genotypes, that will help to dissect drought resistance regulation in this important crop.

In summary, we show that the drought tolerance in PMB-0220 and PHA-0683 common bean accessions is regulated by different molecular mechanisms and that control of the drought-induced senescence seems to be relevant for the better performance of PHA-0683 accession under drought conditions. Our results also suggest that expression patterns of key TF as WRKY53 and WRKY70, or the proline synthesis P5CS, could be used for easy screening of drought resistance/susceptibility in common bean germplasm collections.

\section{Materials and Methods}

\subsection{Growth Conditions and Plant Material}

In this study, P. vulgaris highly drought resistant landrace PHB-0683, originated in Monçao (Portugal) of the market class Cranberry, and the less resistant commercial cultivar Great Northern "Matterhorn" PMB-0220 [12,40,78], were used. Seeds of the two genotypes were sterilized by rinsing with ethanol (100\%) for $30 \mathrm{~s}$, followed by incubation in $5 \%$ sodium hypochlorite for $5 \mathrm{~min}$, washed 5-6 folds with sterile distilled water and placed on wet sterile paper in Petri's dishes for $72 \mathrm{~h}$ to them to germinate. Germinated seeds were sown in pots with a mix of artificial substrate of perlite/vermiculite $(1 / 2 w / w)$. Each pot contained 3 plants that were inoculated at sowing with a fresh suspension of Rhizobium leguminosarum (ISP 14). Plants were watered every third day with the Rigaud and Puppo's nitrogen-free nutrient solution [79]. Plants were grown in a culture chamber with $300 \mu \mathrm{E} \cdot \mathrm{m}^{-2} \cdot \mathrm{s}^{-1}$ lighting for $16 \mathrm{~h}$ at $26^{\circ} \mathrm{C}$ and $8 \mathrm{~h}$ of darkness at $20{ }^{\circ} \mathrm{C}$ and $70 \%$ relative humidity for 28 days. At this time, which coincides with the end of the vegetative stage and beginning of flowering in these two genotypes, the pots were randomly separated into two groups. Nine pots each containing three plants were used for each treatment and genotype. One of the groups was subjected to 10 days of drought by withholding watering and the other was maintained with regular irrigation, as the control one. During the growth of plants, gravimetric determination of soil water content (SWC) was estimated, following the method described in previous works [12]. Finally, samples of the fourth trifoliate leaves were collected, frozen with liquid nitrogen, and stored at $-80^{\circ} \mathrm{C}$ for gene expression and biochemical analyses.

\subsection{Physiological Analysis}

Drought effects on the plant biomass of roots and shoots were measured in the controls, well-irrigated, and drought-stressed plants. Whole plants were collected 10 days after the beginning of the treatment and shoots and roots were weighed to obtain their fresh weight (FW). Tissue samples were desiccated at $75^{\circ} \mathrm{C}$ for $72 \mathrm{~h}$ and weighed again to determine the dry weight (DW). Whole plant biomass was estimated as the sum of roots and shoots dry weights.

Additionally, relative leaf water content (RWC) was measured on the third trifoliate leaf as in previous work [12]. For this, after leaf sampling collection from the control and treated plants, the third trifoliate leaf from each plant was weighted and its FW was obtained. Then, the leaves were soaked with distilled water, left overnight at $4{ }^{\circ} \mathrm{C}$, and its maximum turgor weight (TW) was obtained. Then, the same leaves were dried for $24 \mathrm{~h}$ at $75^{\circ} \mathrm{C}$ to achieve DW and RWC obtained according to the following formula: RWC $(\%)=((\mathrm{FW}-\mathrm{DW}) /(\mathrm{TW}-\mathrm{DW})) \times 100$. 


\subsection{Chlorophyll Determination}

Extraction of total chlorophyll from crushed leaf tissues was done following the method described by Lichtenthaler [80]. Briefly, $1.5 \mathrm{~mL}$ of $80 \%$ acetone was added to $90 \mathrm{mg}$ of tissue. The mix was vortexed to homogenize it, centrifuged at $4{ }^{\circ} \mathrm{C} 3000 \times g$ for $10 \mathrm{~min}$ and the supernatant was collected in tubes kept out of direct light. This procedure was repeated three more times and the four supernatants were mixed. Afterward, the absorbance of the samples was measured at 663 and $645 \mathrm{~nm}$, and the content of chlorophylls estimated according to the following formulas: Chlorophyll A $(\mu \mathrm{g} / \mathrm{mL}=12.25$ $\left.\left(\mathrm{Abs}_{663}\right)-2.79\left(\mathrm{Abs}_{646}\right)\right)$ and chlorophyll B $\left(\mu \mathrm{g} / \mathrm{mL}=21.5\left(\mathrm{Abs}_{646}\right)-5.1\left(\mathrm{Abs}_{663}\right)\right)$ content in leaf tissues was determined. Chlorophyll expressed as $\mathrm{mg} \mathrm{Chl/g} \mathrm{FW.}$

\subsection{Determination of Catalase and Superoxide Dismutase Activities}

Catalase activity was measurement by the disappearance of hydrogen peroxide at $240 \mathrm{~nm}$ [81]. First, the leaf extracts were obtained by homogenizing pulverized tissue with extraction buffer, which contain 100mM phosphate buffer (pH 7); $100 \mathrm{mM}$ EDTA and triton X-100 (0.1\%) v/v, at a relation 1:3 $(w / v)$. The homogenized extracts were centrifuged at $20,000 \times g$ for $10 \mathrm{~min}$ at $4{ }^{\circ} \mathrm{C}$. Then, the supernatants were collected, and low molecular weight compounds were removed by dialysis in a PD Spin Trap G-15 column (GE Healthcare) at $800 \mathrm{~g}$ for $1 \mathrm{~min}$ at $4{ }^{\circ} \mathrm{C}$. Catalase activity was determined using $25 \mu \mathrm{L}$ of crude extract, added to $975 \mu \mathrm{L}$ of reaction buffer, which was composed by $50 \mathrm{mM}$ phosphate buffer ( $\mathrm{pH} 7$ ) and hydrogen peroxide $(0.05 \%)$, and the disappearance of hydrogen peroxide was recorded at $240 \mathrm{~nm}$ for $200 \mathrm{~s}$. Enzyme activity unit was defined as the amount of enzyme decomposing 1.0 mole of hydrogen peroxide per minute. Calculations used an absorbance coefficient of $431 \mathrm{M}^{-1} \mathrm{~cm}^{-1}$. Activity expressed as $\mathrm{U} / \mathrm{mg}$ protein. Total protein content was determined according to Bradford assay [82].

Superoxide dismutase activity was measured using a commercial kit (Canvax biotech, S.L.). Leaf material was homogenized on ice using chilled extraction buffer $(0,1 \mathrm{M}$ tris- $\mathrm{HCl}(\mathrm{pH} 7.4)$; $0,5 \%$ Triton $X-100,5 \mathrm{mM} \beta-\mathrm{ME}$ and $0.1 \mathrm{mg} / \mathrm{mL}$ PMSF) at a relation 1:3 $(w / v)$. Afterward, the mix was centrifuged at $20,000 \times g$ for $10 \mathrm{~min}$ at $4{ }^{\circ} \mathrm{C}$ and the supernatant was collected and dialyzed in a PD Spin Trap G-15 column (GE Healthcare) at $800 \times g$ for 1 min at $4{ }^{\circ} \mathrm{C}$. SOD activity assay was carried out by measuring the disappearance of the colored tetrazolium (WST-1) formazan at $450 \mathrm{~nm}$. SOD activity was estimated by the \% inhibition of formazan obtained by reduction of tetrazolium salts. One-unit SOD specific activity was the amount of protein causing a 50\% inhibition of formazan per mg protein. Bradford assay was used to determine protein content [82].

\subsection{Nucleic Acid Isolation and Quantification}

Total RNA purification was extracted using 50-100 mg of frozen leaf tissue. One mL of Trizol (Nzyol Tzytech) was added to this amount of tissue, homogenized by vortex and incubated for 5 min at room temperature. Next, $200 \mu \mathrm{L}$ of chloroform were added, the mix was homogenized and incubated $8 \mathrm{~min}$ at room temperature. After the incubation, samples were centrifuged at $11,000 \times g$ at $4{ }^{\circ} \mathrm{C}$ for $10 \mathrm{~min}$, and $400-600 \mu \mathrm{L}$ of aqueous phase were collected, transferred to new tubes and $0.8 \mathrm{~V}$ isopropanol were added. After gentle mixing samples were incubated $5 \mathrm{~min}$ at RT and centrifuged at $11,000 \times g$ for $15 \mathrm{~min}$ at $4{ }^{\circ} \mathrm{C}$ to precipitate the RNA and the resulting aqueous phase was removed. Then, $1 \mathrm{~mL}$ of $75 \%$ ethanol was added to the RNA pellet and centrifuged $5 \mathrm{~min}$ at $7500 \times g$ at $4{ }^{\circ} \mathrm{C}$. After this, the supernatant was carefully removed. and the RNA was resuspended in $200 \mu \mathrm{L}$ of miliQ water to which $132 \mu \mathrm{L}$ of lithium chloride $8 \mathrm{M}$ were added and incubated at $0^{\circ} \mathrm{C}$ overnight for a second precipitation of RNA. The RNA samples were centrifuged at $11,000 \times g$ at $4{ }^{\circ} \mathrm{C}$ for $20 \mathrm{~min}$. Supernatant was removed and washed with $75 \%$ ethanol before their last centrifugation at $7500 \times g$ at $4{ }^{\circ} \mathrm{C}$ for $5 \mathrm{~min}$. Afterward, supernatant was removed, RNA pellets let dry for several minutes and resuspended in $40 \mu \mathrm{L}$ of miliQ water. Quantification and purity of the total RNA samples were measured using a NanoDrop spectrophotometer and by visual observation after agarose gel electrophoresis. 


\subsection{Analysis of Gene Expression}

First, genomic DNA was removed from the RNA samples, treatment with DNase I (New England Biolabs) at $37^{\circ} \mathrm{C}$ for $10 \mathrm{~min}$. Synthesis of first strand cDNA was done using $2.5 \mu \mathrm{g}$ of DNase-treated RNA using PrimeScript ${ }^{\mathrm{TM}}$ reverse transcriptase (TAKARA) following the manufacturer's instructions. Analysis of gene expression was carried out by qRT-PCR using iQ SYBR-Green supermix (Bio-Rad) with specific primers for each gene (Supplementary Table S2) in an iCycler iQ System (Bio-Rad). The program used was based in an initial denaturation and an activation of a Taq polymerase at $95^{\circ} \mathrm{C}$ for $5 \mathrm{~min}$ followed of 40 cycles at $95^{\circ} \mathrm{C}$ for $30 \mathrm{~s}, 60^{\circ} \mathrm{C}$ for $30 \mathrm{~s}, 72{ }^{\circ} \mathrm{C}$ for $30 \mathrm{~s}$ and, finally, 80 cycles at $60{ }^{\circ} \mathrm{C}$ for $30 \mathrm{~s}$. Relative expression of each gene for control and drought-stressed samples was normalized to that of Actin-2 and estimated according to Livak and Schmittgen, 2001 [83].

\subsection{Analysis of Promotor Regulatory Motives in WRKY Coding Genes}

$1.5 \mathrm{~Kb}$ DNA sequences of the 5' upstream regions of each gene were obtained from Phytozome database v12 (https://phytozome.jgi.doe.gov/) [84], and search for regulatory cis-elements was done using plant CARE software (http://bioinformatics.psb.ugent.be/webtools/plantcare/html/) [85].

\subsection{Experimental Design and Statistical Analysis of Data}

At least three independent samples were analyzed in this research for each condition (Control and drought) and genotype (PHB-0683 and PHA-0246). Each sample consisted in three pots per condition, each containing three plants. Statistical analysis was done by Student's $t$-test and ANOVA using GraphPad Prism 6 software package (https://www.graphpad.com/).

\section{Conclusions}

Results presented here indicate that the resistance to drought in PMB-0220 and PHA-0683 common bean accessions is regulated by distinct molecular mechanisms. Differential regulation of ABA synthesis and ABA signaling related genes among the two genotypes and the control of the drought-induced senescence have a relevant contribution to the higher resistance level of PHA-0683 accession (Figure 5).

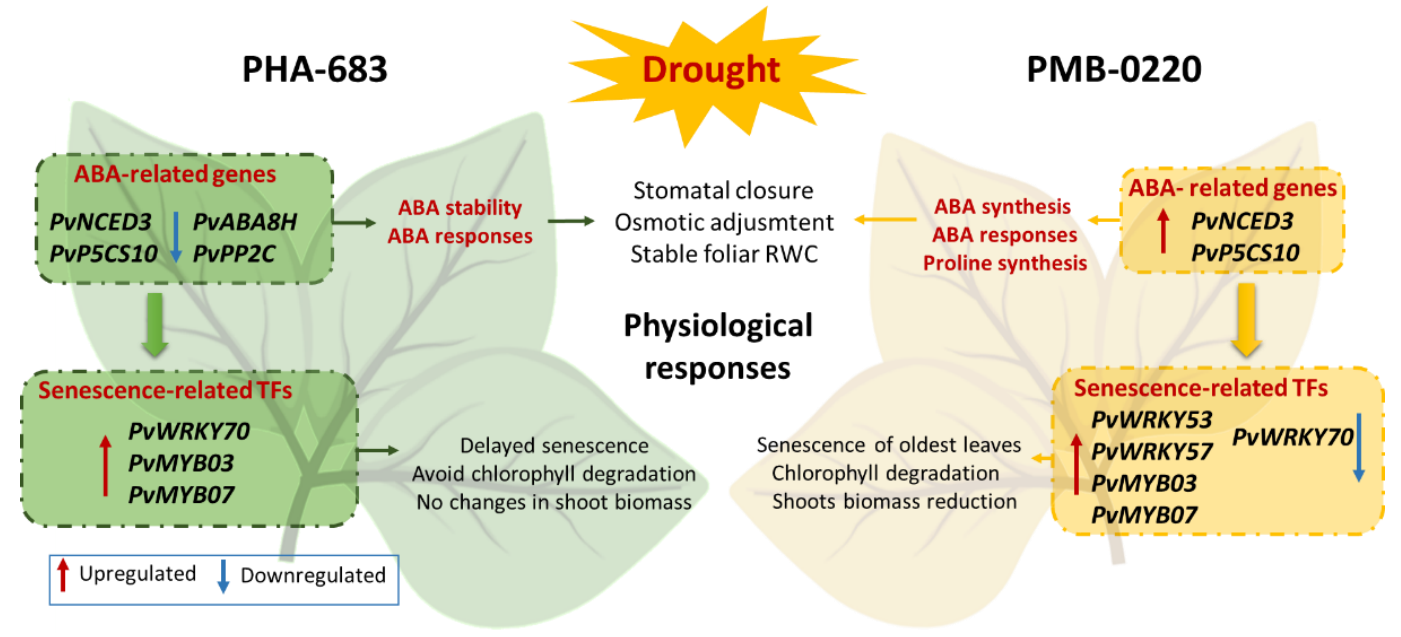

Figure 5. Schematic representation of gene expression patterns of key transcription factors related to senescence and drought responses in leaves from control and 10 days-drought-stressed PMB-0220 and PHA-0683 plants. Only key genes whose expression levels appeared as upregulated or downregulated with respect to control well-irrigated plants are shown.

Supplementary Materials: The following are available online at http://www.mdpi.com/2223-7747/9/12/1815/s1, Table S1: Cis regulatory motifs found in the promoter regions of selected senescence related WRKY genes; Table S2: 
List of primers used in this study. Figure S1: Superoxide dismutase (SOD) (A) and catalase (B) enzymatic activity in leaves from PMB-0220 and PHA-0638 common bean from control and 10 days water-stressed plants.

Author Contributions: Conceptualization, J.M.A.; investigation, J.M.A. and C.M.L.; writing-original draft preparation, J.M.A. and C.M.L.; writing—review and editing, J.M.A. and M.P.; project administration and funding acquisition, J.M.A. and M.P. All authors have read and agreed to the published version of the manuscript.

Funding: This work was supported by Grants: AGL2015-69554-P (Ministerio de Economía y Competitividad, Spain) and BIO-115 (Conserjería de Economía, Innovación, Ciencia, Junta de Andalucía, Spain). CM López-Vazquez was supported by a Fellowship from the University of Córdoba, Spain.

Acknowledgments: We would like to thank A. De Ron (Misión Biológica de Galicia, CSIC, Santiago de Compostela, Spain) for the P. vulgaris seeds used in this work. We also thank the staff of the Central Service for Research Support (SCAI) at the University of Cordoba (Spain) from the University of Córdoba (SCAI) for its technical support.

Conflicts of Interest: The authors declare no conflict of interest. The funders had no role in the design of the study; in the collection, analyses, or interpretation of data; in the writing of the manuscript, or in the decision to publish the results.

\section{References}

1. Broughton, W.J.; Hernández, G.; Blair, M.; Beebe, S.; Gepts, P.; Vanderleyden, J. Beans (Phaseolus spp.)—Model food legumes. Plant Soil. 2003, 252, 55-128. [CrossRef]

2. De Ron, A.M.; Papa, R.; Bitocchi, E.; González, A.M.; Debouck, D.G.; Brick, M.A.; Fourie, D.; Marsolais, F.; Beaver, J.; Geffroy, V.; et al. Common Bean. In Grain Legumes, Handbook of Plant Breeding; Springer: New York, NY, USA, 2015; pp. 1-36.

3. Beebe, S.; Rao, I.M.; Blair, M.W.; Acosta-Gallegos, J.A. Phenotyping common beans for adaptation to drought. Front. Physiol. 2013, 4, 35. [CrossRef]

4. Long, S.P.; Ort, D.R. More than taking the heat: Crops and global change. Curr. Opin. Plant Biol. 2010, 13, 240-247. [CrossRef] [PubMed]

5. Lugtenberg, B.; Kamilova, F. Plant-Growth-Promoting Rhizobacteria. Annu. Rev. Microbiol. 2009, 63, 541-556. [CrossRef] [PubMed]

6. Atkins, C.A. Ammonia assimilation and export of nitrogen from the legume nodule. In Biology and Biochemistry of Nitrogen Fixation; Dilworth, M.J., Glenn, A.R., Eds.; Elsevier Science Publishers: Amsterdam, The Netherlands, 1991; pp. 293-319.

7. Zrenner, R.; Stitt, M.; Sonnewald, U.; Boldt, R. Pyrimidine and Purine Biosynthesis and Degradation In Plants. Annu. Rev. Plant Biol. 2006, 57, 805-836. [CrossRef] [PubMed]

8. Sinclair, T.R.; Serraj, R. Legume nitrogen fixation and drought. Nat. Cell Biol. 1995, 378, 344. [CrossRef]

9. King, C.A.; Purcell, L.C. Inhibition of N2 Fixation in Soybean Is Associated with Elevated Ureides and Amino Acids1. Plant Physiol. 2005, 137, 1389-1396. [CrossRef]

10. Gil-Quintana, E.; Larrainzar, E.; Seminario, A.; Díaz-Leal, J.L.; Alamillo, J.M.; Pineda, M.; Arrese-Igor, C.; Wienkoop, S.; González, E.M. Local inhibition of nitrogen fixation and nodule metabolism in drought-stressed soybean. J. Exp. Bot. 2013, 64, 2171-2182. [CrossRef]

11. Alamillo, J.M.; Díaz-Leal, J.L.; Pineda, M.; Sánchez-Moran, M.V. Molecular analysis of ureide accumulation under drought stress in Phaseolus vulgaris L. Plant Cell Environ. 2010, 33, 1828-1837. [CrossRef]

12. Coleto, I.; Pineda, M.; Rodiño, A.P.; De Ron, A.M.; Alamillo, J.M. Comparison of inhibition of N2 fixation and ureide accumulation under water deficit in four common bean genotypes of contrasting drought tolerance. Ann. Bot. 2014, 113, 1071-1082. [CrossRef]

13. Takagi, H.; Ishiga, Y.; Watanabe, S.; Konishi, T.; Egusa, M.; Akiyoshi, N.; Matsuura, T.; Mori, I.C.; Hirayama, T.; Kaminaka, H.; et al. Allantoin, a stress-related purine metabolite, can activate jasmonate signaling in a MYC2-regulated and abscisic acid-dependent manner. J. Exp. Bot. 2016, 67, 2519-2532. [CrossRef] [PubMed]

14. Watanabe, S.; Matsumoto, M.; Hakomori, Y.; Takagi, H.; Shimada, H.; Sakamoto, A. The purine metabolite allantoin enhances abiotic stress tolerance through synergistic activation of abscisic acid metabolism. Plant Cell Environ. 2013, 37, 1022-1036. [CrossRef] [PubMed]

15. Roychoudhury, A.; Paul, S.; Basu, S. Cross-talk between abscisic acid-dependent and abscisic acid-independent pathways during abiotic stress. Plant Cell Rep. 2013, 32, 985-1006. [CrossRef] [PubMed]

16. Seo, M.; Koiwai, H.; Akaba, S.; Komano, T.; Oritani, T.; Kamiya, Y.; Koshiba, T. Abscisic aldehyde oxidase in leaves of Arabidopsis thaliana. Plant J. 2000, 23, 481-488. [CrossRef] 
17. Seo, M.; Peeters, A.J.M.; Koiwai, H.; Oritani, T.; Marion-Poll, A.; Zeevaart, J.A.D.; Koornneef, M.; Kamiya, Y.; Koshiba, T. The Arabidopsis aldehyde oxidase 3 (AAO3) gene product catalyzes the final step in abscisic acid biosynthesis in leaves. Proc. Natl. Acad. Sci. USA 2000, 97, 12908-12913. [CrossRef]

18. Dong, T.; Park, Y.; Hwang, I. Abscisic acid: Biosynthesis, inactivation, homoeostasis and signalling. Essays Biochem. 2015, 58, 29-48. [CrossRef]

19. Zhu, J.-K. Salt and Drought Stress Signal Transduction Inplants. Annu. Rev. Plant Biol. 2002, 53, $247-273$. [CrossRef]

20. Farquhar, G.D.; Sharkey, T.D. Stomatal Conductance and Photosynthesis. Annu. Rev. Plant Physiol. 1982, 33, 317-345. [CrossRef]

21. Rivero, R.M.; Kojima, M.; Gepstein, A.; Sakakibara, H.; Mittler, R.; Gepstein, S.; Blumwald, E. Delayed leaf senescence induces extreme drought tolerance in a flowering plant. Proc. Natl. Acad. Sci. USA 2007, 104, 19631-19636. [CrossRef]

22. Zabadal, T.J. A Water Potential Threshold for the Increase of Abscisic Acid in Leaves. Plant Physiol. 1974, 53, 125-127. [CrossRef]

23. Ma, Y.; Szostkiewicz, I.; Korte, A.; Moes, D.; Yang, Y.; Christmann, A.; Grill, E. Regulators of PP2C Phosphatase Activity Function as Abscisic Acid Sensors. Science 2009, 324, 1064-1069. [CrossRef]

24. Park, S.; Fung, P.; Nishimura, N.; Jensen, D.R.; Fujii, H.; Zhao, Y.; Lumba, S.; Santiago, J.; Rodrigues, A.; Chow, T.F.; et al. Abscisic acid inhibits PP2Cs via the PYR/PYL family of ABA- binding START proteins. Science 2010, 324, 1068-1071. [CrossRef]

25. Rodrigues, A.; Adamo, M.; Crozet, P.; Margalha, L.; Confraria, A.; Martinho, C.; Elias, A.; Rabissi, A.; Lumbreras, V.; González-Guzmán, M.; et al. ABI1 and PP2CA Phosphatases Are Negative Regulators of Snf1-Related Protein Kinase1 Signaling in Arabidopsis. Plant Cell 2013, 25, 3871-3884. [CrossRef]

26. Fujita, Y.; Nakashima, K.; Yoshida, T.; Katagiri, T.; Kidokoro, S.; Kanamori, N.; Umezawa, T.; Fujita, M.; Maruyama, K.; Ishiyama, K.; et al. Three SnRK2 Protein Kinases are the Main Positive Regulators of Abscisic Acid Signaling in Response to Water Stress in Arabidopsis. Plant Cell Physiol. 2009, 50, 2123-2132. [CrossRef] [PubMed]

27. Fujii, H.; Chinnusamy, V.; Rodrigues, A.; Rubio, S.; Antoni, R.; Park, S.-Y.; Cutler, S.R.; Sheen, J.; Rodriguez, P.L.; Zhu, J.-K. In vitro reconstitution of an abscisic acid signalling pathway. Nat. Cell Biol. 2009, 462, 660-664. [CrossRef] [PubMed]

28. Uauy, C.; Distelfeld, A.; Fahima, T.; Blechl, A.; Dubcovsky, J. A NAC Gene Regulating Senescence Improves Grain Protein, Zinc, and Iron Content in Wheat. Science 2006, 314, 1298-1301. [CrossRef]

29. Riov, J.; Dagan, E.; Goren, R.; Yang, S.F. Characterization of Abscisic Acid-Induced Ethylene Production in Citrus Leaf and Tomato Fruit Tissues. Plant Physiol. 1990, 92, 48-53. [CrossRef]

30. Zhao, Y.; Chan, Z.; Gao, J.; Xing, L.; Cao, M.; Yu, C.; Hu, Y.; You, J.; Shi, H.; Zhu, Y.; et al. ABA receptor PYL9 promotes drought resistance and leaf senescence. Proc. Natl. Acad. Sci. USA 2016, 113, 1949-1954. [CrossRef]

31. Liu, L.; Xu, W.; Hu, X.; Liu, H.; Lin, Y. W-box and G-box elements play important roles in early senescence of rice flag leaf. Sci. Rep. 2016, 6, 20881. [CrossRef]

32. Zou, X.; Seemann, J.R.; Neuman, D.; Shen, Q.J. A WRKY Gene from Creosote Bush Encodes an Activator of the Abscisic Acid Signaling Pathway. J. Biol. Chem. 2004, 279, 55770-55779. [CrossRef]

33. Chen, L.; Song, Y.; Li, S.; Zhang, L.; Zou, C.; Yu, D. The role of WRKY transcription factors in plant abiotic stresses. Biochim. Biophys. Acta (BBA) Bioenerg. 2012, 1819, 120-128. [CrossRef] [PubMed]

34. Ülker, B.; Somssich, I.E. WRKY transcription factors: From DNA binding towards biological function. Curr. Opin. Plant Biol. 2004, 7, 491-498. [CrossRef] [PubMed]

35. Wu, J.; Chen, J.; Wang, L.; Wang, S. Genome-Wide Investigation of WRKY Transcription Factors Involved in Terminal Drought Stress Response in Common Bean. Front. Plant Sci. 2017, 8, 1-12. [CrossRef] [PubMed]

36. Schmutz, J.; Cannon, S.B.; Schlueter, J.A.; Ma, J.; Mitros, T.; Nelson, W.; Hyten, D.L.; Song, Q.; Thelen, J.J.; Cheng, J.; et al. Genome sequence of the palaeopolyploid soybean. Nature 2010, 463, 178-183. [CrossRef] [PubMed]

37. Hummel, M.; Hallahan, B.F.; Brychkova, G.; Ramirez-Villegas, J.; Guwela, V.; Chataika, B.; Curley, E.; McKeown, P.C.; Morrison, L.; Talsma, E.F.; et al. Reduction in nutritional quality and growing area suitability of common bean under climate change induced drought stress in Africa. Sci. Rep. 2018, 8, 1-11. [CrossRef] [PubMed] 
38. Frahm, M.A.; Rosas, J.C.; Mayek-Pérez, N.; López-Salinas, E.; Acosta-Gallegos, J.A.; Kelly, J.D.; Aggarwal, V.D.; Pastor-Corrales, M.A.; Chirwa, R.M.; Buruchara, R.A. Breeding beans for resistance to terminal drought in the Lowland tropics. Euphytica 2004, 136, 223-232. [CrossRef]

39. Riveiro, M. Tolerancia de Variedades de Judía a Estrés Hídrico Estacional e Implicaciones en la Fijación Simbiótica de Nitrógeno. Ph.D. Thesis, Universidad de Santiago de Compostela, Santiago de Compostela, Spain, 2012.

40. Muñoz-Perea, C.G.; Terán, H.; Allen, R.G.; Wright, J.L.; Westermann, D.T.; Singh, S.P. Selection for Drought Resistance in Dry Bean Landraces and Cultivars. Crop. Sci. 2006, 46, 2111-2120. [CrossRef]

41. Terán, H.; Singh, S.P. Comparison of Sources and Lines Selected for Drought Resistance in Common Bean. Crop. Sci. 2002, 42, 64-70. [CrossRef]

42. Chen, W.; Yao, Q.; Patil, G.B.; Agarwal, G.; Deshmukh, R.K.; Lin, L.; Wang, B.; Wang, Y.; Prince, S.J.; Song, L.; et al. Identification and Comparative Analysis of Differential Gene Expression in Soybean Leaf Tissue under Drought and Flooding Stress Revealed by RNA-Seq. Front. Plant Sci. 2016, 7, 1044. [CrossRef]

43. Mashaki, K.M.; Garg, V.; Ghomi, A.A.N.; Kudapa, H.; Chitikineni, A.; Nezhad, K.Z.; Yamchi, A.; Soltanloo, H.; Varshney, R.K.; Thudi, M. RNA-Seq analysis revealed genes associated with drought stress response in kabuli chickpea (Cicer arietinum L.). PLoS ONE 2018, 13, e0199774. [CrossRef]

44. Morgil, H.; Tardu, M.; Cevahir, G.; Kavakli, I.H. Comparative RNA-seq analysis of the drought-sensitive lentil (Lens culinaris) root and leaf under short- and long-term water deficits. Funct. Integr. Genom. 2019, 19, 715-727. [CrossRef] [PubMed]

45. Wu, J.; Wang, L.; Li, L.; Wang, S. De Novo Assembly of the Common Bean Transcriptome Using Short Reads for the Discovery of Drought-Responsive Genes. PLoS ONE 2014, 9, e109262. [CrossRef] [PubMed]

46. Jorge, J.G.; Villalobos-López, M.A.; Chavarría-Alvarado, K.L.; Ríos-Meléndez, S.; López-Meyer, M.; Arroyo-Becerra, A. Genome-wide transcriptional changes triggered by water deficit on a drought-tolerant common bean cultivar. BMC Plant Biol. 2020, 20, 525. [CrossRef]

47. López, C.M.; Pineda, M.; Alamillo, J.M. Transcriptomic Response to Water Deficit Reveals a Crucial Role of Phosphate Acquisition in a Drought-Tolerant Common Bean Landrace. Plants 2020, 9, 445. [CrossRef]

48. Bai, G.; Xie, H.; Yao, H.; Li, F.; Chen, X.; Zhang, Y.; Xiao, B.; Yang, J.; Li, Y.; Yang, D.-H. Genome-wide identification and characterization of ABA receptor PYL/RCAR gene family reveals evolution and roles in drought stress in Nicotiana tabacum. BMC Genom. 2019, 20, 575. [CrossRef]

49. Miao, Y.; Laun, T.; Zimmermann, P.; Zentgraf, U. Targets of the WRKY53 transcription factor and its role during leaf senescence in Arabidopsis. Plant Mol. Biol. 2004, 55, 853-867. [CrossRef]

50. Besseau, S.; Li, J.; Palva, E.T. WRKY54 and WRKY70 co-operate as negative regulators of leaf senescence in Arabidopsis thaliana. J. Exp. Bot. 2012, 63, 2667-2679. [CrossRef]

51. Abe, H.; Yamaguchi-Shinozaki, K.; Urao, T.; Iwasaki, T.; Hosokawa, D. Role of arabidopsis MYC and MYB homologs in drought- and abscisic acid-regulated gene expression. Plant Cell 1997, 9, 1859-1868. [CrossRef]

52. Zhou, Q.-Y.; Tian, A.-G.; Zou, H.-F.; Xie, Z.-M.; Lei, G.; Huang, J.; Wang, C.-M.; Wang, H.-W.; Zhang, J.; Chen, S. Soybean WRKY-type transcription factor genes, GmWRKY13, GmWRKY21, and GmWRKY54, confer differential tolerance to abiotic stresses in transgenic Arabidopsis plants. Plant Biotechnol. J. 2008, 6, 486-503. [CrossRef]

53. Singh, S.P. Drought Resistance in the Race Durango Dry Bean Landraces and Cultivars. Agron. J. 2007, 99, 1219-1225. [CrossRef]

54. Lizana, C.; Wentworth, M.; Martinez, J.P.; Villegas, D.; Meneses, R.; Murchie, E.H.; Pastenes, C.; Lercari, B.; Vernieri, P.; Horton, P.; et al. Differential adaptation of two varieties of common bean to abiotic stress. J. Exp. Bot. 2006, 57, 685-697. [CrossRef] [PubMed]

55. Tuteja, N. Abscisic Acid and Abiotic Stress Signaling. Plant Signal. Behav. 2007, 2, 135-138. [CrossRef] [PubMed]

56. Iuchi, S.; Kobayashi, M.; Taji, T.; Naramoto, M.; Seki, M.; Kato, T.; Tabata, S.; Kakubari, Y.; Yamaguchi-Shinozaki, K.; Shinozaki, K. Regulation of drought tolerance by gene manipulation of 9-cis-epoxycarotenoid dioxygenase, a key enzyme in abscisic acid biosynthesis in Arabidopsis. Plant J. 2001, 27, 325-333. [CrossRef] [PubMed]

57. Qin, X.; Zeevaart, J.A.D. The 9-cis-epoxycarotenoid cleavage reaction is the key regulatory step of abscisic acid biosynthesis in water-stressed bean. Proc. Natl. Acad. Sci. USA 1999, 96, 15354-15361. [CrossRef] [PubMed] 
58. Seo, M. Complex regulation of ABA biosynthesis in plants. Trends Plant Sci. 2002, 7, 41-48. [CrossRef]

59. Cutler, S.R.; Rodriguez, P.L.; Finkelstein, R.R.; Abrams, S.R. Abscisic Acid: Emergence of a Core Signaling Network. Annu. Rev. Plant Biol. 2010, 61, 651-679. [CrossRef] [PubMed]

60. Krochko, J.E.; Abrams, G.D.; Loewen, M.K.; Abrams, S.R.; Cutler, A.J. (+)-Abscisic Acid 8'-Hydroxylase Is a Cytochrome P450 Monooxygenase. Plant Physiol. 1998, 118, 849-860. [CrossRef]

61. Nambara, E.; Marion-Poll, A. Abscisic Acid Biosynthesis and Catabolism. Annu. Rev. Plant Biol. 2005, 56, 165-185. [CrossRef]

62. Roychoudhury, A.; Banerjee, A.; Lahiri, V. Metabolic and molecular-genetic regulation of proline signaling and itscross-talk with major effectors mediates abiotic stress tolerance in plants. Turk. J. Bot. 2015, 39, 887-910. [CrossRef]

63. Kishor, P.B.K.; Sreenivasulu, N. Is proline accumulation perse correlated with stress tolerance or is proline homeostasis a more critical issue? Plant Cell Environ. 2013, 37, 300-311. [CrossRef]

64. Szabados, L.; Savouré, A. Proline: A multifunctional amino acid. Trends Plant Sci. 2010, 15, 89-97. [CrossRef] [PubMed]

65. Székely, G.; Abraham, E.; Cseplo, A.; Rigor, G.; Zsigmond, L.; Csiszãarr, J.; Ayaydin, F.; Strizhov, N.; Jãjsik, J.; Schmelzer, E.; et al. Duplicated P5CS genes of Arabidopsis play distinct roles in stress regulation and developmental control of proline biosynthesis. Plant J. 2008, 53, 11-28. [CrossRef] [PubMed]

66. Arteaga, S.; Yabor, L.; Díez, M.J.; Prohens, J.; Boscaiu, M.; Vicente, O. The Use of Proline in Screening for Tolerance to Drought and Salinity in Common Bean (Phaseolus vulgaris L.) Genotypes. Agronomy 2020, 10, 817. [CrossRef]

67. Hossain, M.A.; Hoque, A.; Burritt, D.J.; Fujita, M. Proline Protects Plants Against Abiotic Oxidative Stress. In Oxidative Damage to Plants; Elsevier BV: Amsterdam, The Netherlands, 2014; Volume 2014, pp. 477-522.

68. Gan, S.; Amasino, R.M. Inhibition of Leaf Senescence by Autoregulated Production of Cytokinin. Science 1995, 270, 1986-1988. [CrossRef]

69. Yang, J.C.; Zhang, J.; Wang, Z.Q.; Zhu, Q.S.; Liu, L.J. Involvement of abscisic acid and cytokinins in the senescence and remobilization of carbon reserves in wheat subjected to water stress during grain filling. Plant Cell Environ. 2003, 26, 1621-1631. [CrossRef]

70. Jiang, Y.; Liang, G.; Yu, D. Activated Expression of WRKY57 Confers Drought Tolerance in Arabidopsis. Mol. Plant 2012, 5, 1375-1388. [CrossRef]

71. Kazan, K.; Manners, J.M. MYC2: The Master in Action. Mol. Plant 2013, 6, 686-703. [CrossRef]

72. Guo, Y.; Gan, S.-S. AtMYB2 Regulates Whole Plant Senescence by Inhibiting Cytokinin-Mediated Branching at Late Stages of Development in Arabidopsis. Plant Physiol. 2011, 156, 1612-1619. [CrossRef]

73. Zentgraf, U.; Doll, J. Arabidopsis WRKY53, a Node of Multi-Layer Regulation in the Network of Senescence. Plants 2019, 8, 578. [CrossRef]

74. Lim, P.O.; Kim, H.J.; Gil Nam, H. Leaf Senescence. Annu. Rev. Plant Biol. 2007, 58, 115-136. [CrossRef]

75. Hörtensteiner, S. Chlorophyll Degradation During Senescence. Annu. Rev. Plant Biol. 2006, 57, 55-77. [CrossRef] [PubMed]

76. Christ, B.; Hörtensteiner, S. Mechanism and Significance of Chlorophyll Breakdown. J. Plant Growth Regul. 2014, 33, 4-20. [CrossRef]

77. Volaire, F.; Norton, M. Summer Dormancy in Perennial Temperate Grasses. Ann. Bot. 2006, 98, 927-933. [CrossRef] [PubMed]

78. Kelly, J.D.; Hosfield, G.L.; Varner, G.V.; Uebersax, M.A.; Taylor, J. Registration of “Matterhorn” Great Northern Bean. Crop. Sci. 1999, 39, 589-590. [CrossRef]

79. Rigaud, J.; Puppo, A. Indole-3-acetic Acid Catabolism by Soybean Bacteroids. J. Gen. Microbiol. 1975, 88, 223-228. [CrossRef]

80. Lichtenthaler, H.K. Chlorophylls and Carotenoids: Pigments of Photosynthetic Biomembranes. In Methods in Enzymology; Academic Press: Orlando, FL, USA, 1987; Volume 148, pp. 183-350.

81. Konieczny, R.; Banaś, A.K.; Surówka, E.; Michalec, Ż.; Miszalski, Z.; Libik-Konieczny, M. Pattern of antioxidant enzyme activities and hydrogen peroxide content during developmental stages of rhizogenesis from hypocotyl explants of Mesembryanthemum crystallinum L. Plant Cell Rep. 2013, 33, 165-177. [CrossRef]

82. Bradford, M.M. A rapid and sensitive method for the quantitation of microgram quantities of protein utilizing the principle of protein-dye binding. Anal. Biochem. 1976, 72, 248-254. [CrossRef] 
83. Livak, K.J.; Schmittgen, T.D. Analysis of relative gene expression data using real-time quantitative PCR and the $2^{-\Delta \Delta C T}$ Method. Methods 2001, 25, 402-408. [CrossRef]

84. Schmutz, J.; McClean, P.E.; Mamidi, S.; Wu, G.A.; Cannon, S.B.; Grimwood, J.; Jenkins, J.; Shu, S.; Song, Q.; Chavarro, C.; et al. A reference genome for common bean and genome-wide analysis of dual domestications. Nat. Genet. 2014, 46, 707-713. [CrossRef]

85. Lescot, M.; Déhais, P.; Thijs, G.; Marchal, K.; Moreau, Y.; Van De Peer, Y.; Rouzé, P.; Rombauts, S. PlantCARE, a database of plant cis-acting regulatory elements and a portal to tools for in silico analysis of promoter sequences. Nucleic Acids Res. 2002, 30, 325-327. [CrossRef]

Publisher's Note: MDPI stays neutral with regard to jurisdictional claims in published maps and institutional affiliations.

(C) 2020 by the authors. Licensee MDPI, Basel, Switzerland. This article is an open access article distributed under the terms and conditions of the Creative Commons Attribution (CC BY) license (http://creativecommons.org/licenses/by/4.0/). 